\title{
ニッケル単結晶下部組織の $\mathrm{X}$ 線的研究
}

\section{前田繁男*}

Shigeo Maeda: X-ray Studies on Sub-structures in Single Crystals of Nickel.

An examination was carried out by the $\mathrm{X}$-ray diffraction microscopy with respect to misoriented sub-structures in the crystals which had been grown from the melt in the [001] direction. It is found that within the range of the lowering speed from 1 to $10 \mathrm{~mm} / \mathrm{min}$, the specimen consists of the two types of sub-structure whose boundaries extend together in the direction parallel to the [001] axis. One type of sub-structure is that which is termed "striations" and the other is the sub-structure, developed by branching off of sub-boundaries during the growth. A mechanism of the latter formation is discussed on the basis of the fact that supercooling liquid exists inside the groove which is formed at the solid-liquid interface meeting the sub-boundary.

(Received August 29, 1961)

\section{I. 緒言}

上く知られているように愹融凝固法で作つた金属単結晶 は,凝固過程に括いて生じた数種の下部組織を含んでいる。 現在これらの下部組織はその素因より，不純物の不均一な 分布に上る飞のと，枟位の特殊な配列に上るもの，すなわ ち,相互に結晶方位差をもつ下部組織とに大別されている。

本報执いては，種々の成镕条件のもとで作つたニッヶ ル単結晶のX線的観察から, 主に後者に属する下部組織の 性質を調べ，顕微鏡による観察結果(1)と対照してその成因 そついて考察した

\section{II. 実験 方 法}

試料として純度 $98.51 \%$ \%抒よび $99.21 \%$ ニッケルを 使用した。 その分析值を Table 1 と示す.

Table 1 Chemical composition of specimens. (\%)

\begin{tabular}{c|c|c|c|c|c|c}
\hline \hline $\mathrm{Ni}$ & $\mathrm{Co}$ & $\mathrm{C}$ & $\mathrm{Fe}$ & $\mathrm{Cu}$ & $\mathrm{Mn}$ & $\mathrm{Mg}$ \\
\hline 98.51 & 0.85 & 0.02 & 0.21 & 0.01 & 0.22 & 0.18 \\
99.21 & 0.78 & 0.002 & 0.002 & 0.002 & tr. & tr. \\
\hline
\end{tabular}

実験は [001]方向に成長させた棒状単結晶について行な つた．試料の製作，研䄷等は前報(1)と同様な方法を用いた が, しかし, この製作方法では, 試料と坩腡との膨張係数 が異なるために，凝固後に発生する歪，西るい磁製管か ら試料を取り出す際の不注意な取扰いによる歪などを考虑 しなければならない。この点を確かめるために，磁製管の 代りに Fig.1 亿示す卡うな soft-mold 法(2)を利用した特 殊な㙋城を使用した。すなわち，アルミナ粉末に水を加え て泥状にしたものをモリブデンの容器に流し込み，この中 に予め成型した短冊型の試料と，その下端に接して [001]

* 京都大学化学研究所

(1) 高木, 前田, 中井: 本誌, 21 (1957), 658 .

$\dagger$ 前報(1) 亿使用した試料と同純度のものであり, 前報 の純度 $99.36 \%$ は Ni+Co の值である.

(2) T.S. Noggle: Rev. Sci. Instr., $24(1953), 184$
方向の種の結晶とを短冊の側面が (100) 面になるように埋 め，モリブデン板で蓋をする。これを air bath 中にて一。 |度乾燥した後, 磁製管を用いた場合と.同様

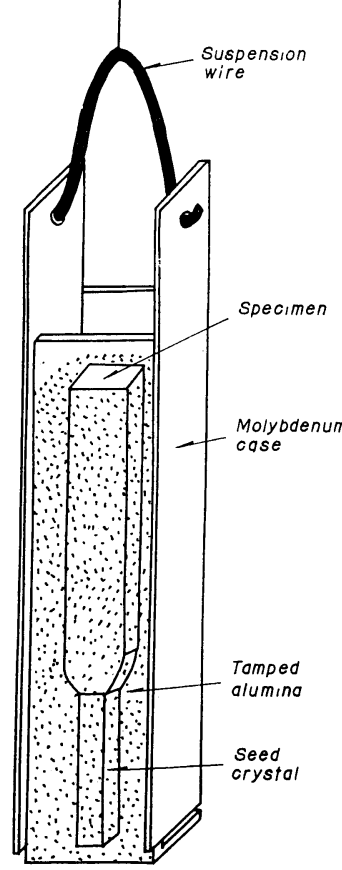

Fio.1 Schematic diagram of a crucible made by the soft mold technique. な方法で結晶成俳を行なう。 できた単結晶は最初に成型し た形を保ちまたアルミナ粉 水から容易に離すことができ るから電解研磨のみに上り観 察面が得られる。

下部組織の観察にはX X線回 折顕微法と透過型単色器を用 いる方法とを併用した. 前者 は Berg(3), Barret(4) によつ て発展したもので, その後西 山ら(5)(6)によつてさらに詳細 な研究がなされている．著者 は西山と同様な装置を用い, [001]方向に成長させた試料 の側面 (100)面を，(204)の反 射面によって観察した，X線 は銅-Kaを朋い, 入射方向に 垂直な面内での焦点の見掛け の大きさは $0.4 \times 2.6 \mathrm{mrn}^{2} て ゙$ ある・本方法は主に下部組織 の形態を観察する目的で使用 したから，下部組織の外形が 明確に，また比較的大きな方位差をもつ下部組織も同一乾 板に写ることが望ましい。このため, 試䉼面内で試料軸に 垂直な回転軸を，焦点から $20 \mathrm{~cm}$ の距離において焦点の 短軸と平行に置いた。この場合, 試料面の反射可能範囲は $10 \mathrm{~mm}$, 試料軸方向の感度は $1^{\circ}$ ，また乾板上で試料軸に 直角な方向の分解能は，回転軸より $10 \mathrm{~mm}$ の位置で $8 \mu$

(3) W. Berg: Naturwiss., 19 (1931) ,391.

(4) C.S. Barrett: Trans. AIME, $161(1945), 15$.

(5) 山本, 土居, 西山：応用物理, 24 (1955), 368.

(6) 山本, 西山：応用物理, $24(1955), 234$. 
となり,これは $1^{\prime}$ 以下の方位差に相当する. 以下の写真で 成長方向は左から右へ，またX線は逆方向から入射してい る.写真で白い部分がX線の強いところであり, 試料軸に 直角な黒い線は試料面に引いた疪で，このずれから大体の 方位差を知り得る。

後者は加藤(7)に上り考案された方法で, 彎曲水晶片を透 過させることによつて特性 $\mathrm{X}$ 線（銅- $\mathrm{K} \alpha)$ を収斂し，試料 面上飞尖鋭な線状の形で入射させ，入射位置に括ける結晶 の乱れを反射 X線に垂直に置かれた乾板上の反射像のずれ から求めた. 試料面は X線回折顕微法の場合と同じ (100) 面, 用いた反射面は (200) 面で, 収斂X線が試料軸任值角 になるように入射させた，この場合試料軸抽よび試料面内 でこれと直角な軸の回りの方位差， $\Delta \phi, \Delta \theta$ は次式で与え られる。

$$
\Delta \dot{\phi}=\frac{\Delta x}{2 L \sin \theta}, \quad \Delta \theta=\frac{\Delta y}{L^{-}}
$$

ここで $\Delta y, \Delta x$ は陚料軸方向拉よびこれと直角方向の反射 像のずれ， $\theta$ は Bragg angle， $L$ は試料面から反射像まで の距離である。

\section{III. 実 験 結 果}

一般化細胞組織は成長速度が遅くなるとでき難くなる。 ニッケルに沶いても降下速度が $0.5 \mathrm{~mm} / \mathrm{min}$ 以下になる と，試料上端に見られる細胞は急速に大さくなり，同時に 形も不規則となる(1)。この降下速度範囲で成長させた試料 では, その側断面のX線回折顕微法による観察から, 分解

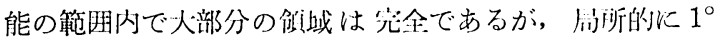

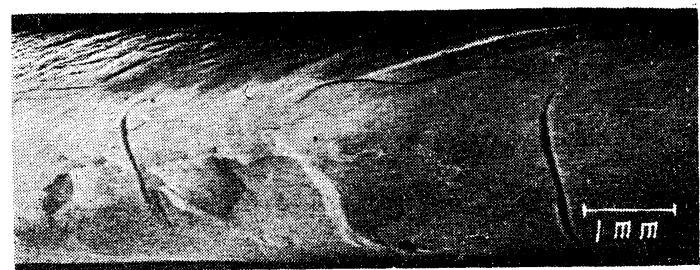

Photo.1 X-ray micrograph on the side surface. Direction of growth, [001]. Lowering speed, $0.35 \mathrm{~mm} / \mathrm{min} 99.21 \%$ pure $\mathrm{Ni}$.

程度の比較的大きな方位差をもつ島状の下部組織が認めら れる(Photo.1)。同㥞な下部組織はまた soft-mold 法を 用いて作つた試料活いて子観察される。

降下速度が $1 \mathrm{~mm} / \mathrm{min}$ に近くなると, 約 $1 \mathrm{~mm}$ 閒隔で, $1^{\circ}$ 程度の方位差をるつ小角度西境界が 試料軸に ほ 飞現われる(Photo.2)．この小角度亜境界は従来報告され ている下部組織とは異なり, 成長過程にある小角度亜境界 が分裂することによつて発生する(例兄ば Photo.2, 矢印の 位置)．新たにできた 2 条の小角度覀境界は最初試料軸と 劣る傾きをるつて成長し，両者の間隔が $1 \mathrm{~mm}$ 位に達した

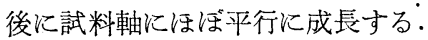

降下速度が $1 \mathrm{~mm} / \mathrm{min}$ を越える試料ではさきに述べた

(7) N. Kato: Acta Met., 5(1957),237.
小角度亜境界とは別に，顕微鏡にて観察される線状組織の 境界に沿つて現われ，成長とと画に一定の角度まで徐々に

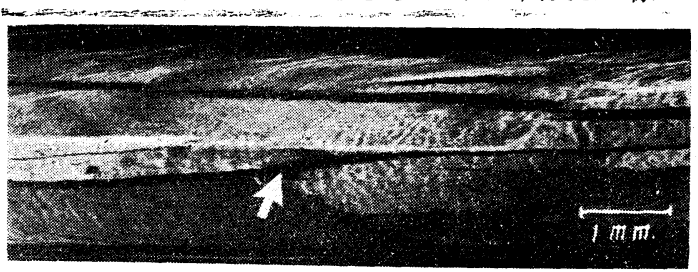

Photo.2 X-ray micrograph on the side surface. Direction of growtb, [001]. Lowering speed, $1.0 \mathrm{~mm} / \mathrm{min} 99.21 \%$ pure $\mathrm{Ni}$.

方位差を增す亚境界が観察される(Photo.3 矢印の位置). この亜境界は, Teghtsonian(8)ら抢よび小山(9)が錫につい て観察した筋 (striation) 飞相当すると考学られる.Photo. 3 の試料の覀境觜の方位差についてはさらに透過型単色器

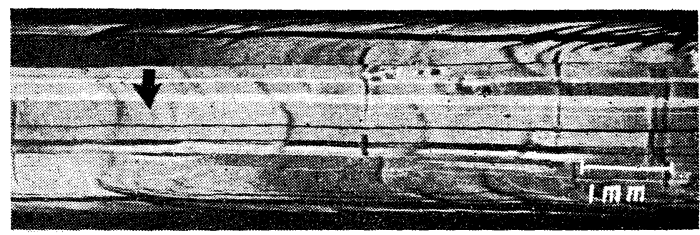

Photo.3 X-ray micrograph on the side surface. Direction of growth, [001]. Lowering speed, $2.2 \mathrm{~mm} / \mathrm{min} 99.21 \%$ pure $\mathrm{Ni}$.

を用いて調べた $($ Photo.4)*. 写真で各反射像に付けた番 号は, 試料軸に直角汇試料の一端から他端に向つて配列し た下部組織の順序を示すが，小角度境界は，例えば像 5 と 6 , あるいは 9 と 10 の間隔によつて示されるよ 5 に試料

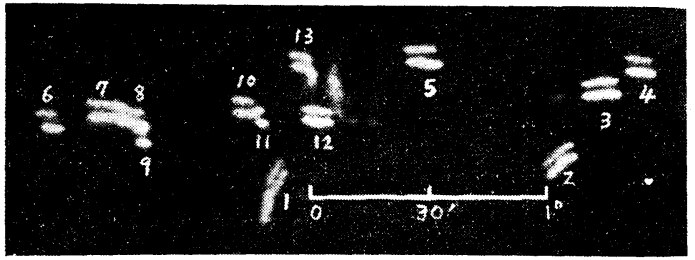

Photo.4 X-ray photograph taken by the use of transmission type monochromater. The specimen used is the same as that in photo.3.

軸の回りに $1^{\circ}$ 前後の方位差をるつが，また小角度亜境界 の闑に市つて，筋に対応する亜境界は数分の方位差をるつ ことが判る. Photo. 3 の陚料よりも早い、降下速度の陚料で は, 筋組織は線状組織の境界の殆んどすべてに沿つて現わ れる (Photo.5). この試料の試料軸便值な切断面のX線 回折顕微像では顕微鏡像と一致した細胞䦎に方位差が認め られるが，同時に数個の細胞を含み，その外形に沿つてさ らに大きな方位差をもつ亜境界が観察される(Photo.6).

Table 2 は Photo. 5 の陚料炕つい, Photo. 4 の場合之同

(8) E. Teghtsonian, B. Chalmers: Can. J. Phys., $30(1952), 388$

(9) 小山：本誌, $22(1958), 544$.

* 1,2 呿上び 13 の像が縦に 伸びているのは, 試料の 外形が彎曲しているためである。 
様な方法で測定した亜境界の方位差 (a) および成長方向に 沿つて $3 \mathrm{~mm}$ 間隔每に調べた方位差 (b) の值を示す．小角

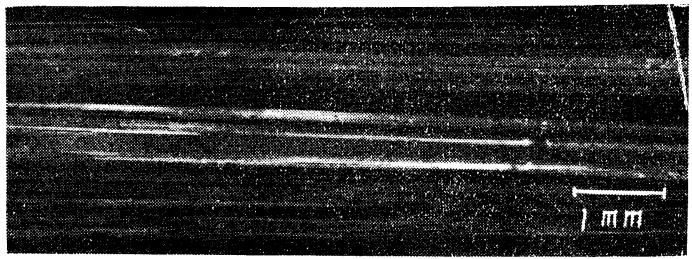

Photo.5 X-ray micrograph on the side surface. Direction of growth, [001]. Lowering speed, $6.3 \mathrm{~mm} / \mathrm{min} 99.21 \%$ pure $\mathrm{Ni}$.

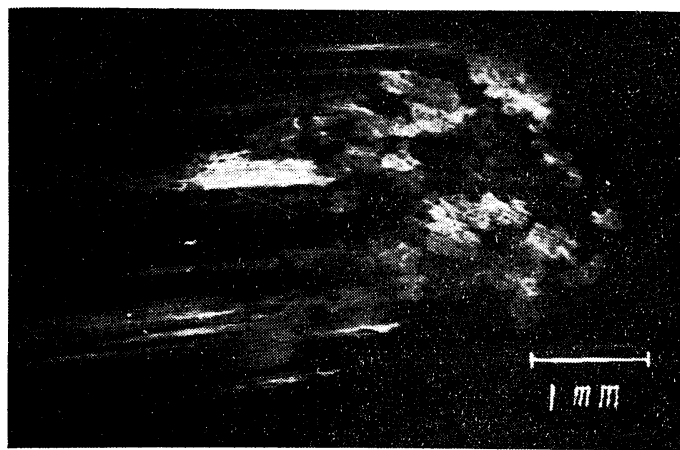

Photo.6 X-ray micrograph on the sectional surface, (001). Lowering speed, $6.3 \mathrm{~mm}$ $/$ min $99.21 \%$ pure $\mathrm{Ni}$. Line appearing on the left side are due to the reflection on the side surface.

Table 2 Orientation, differences between the substructures on the side surface of the specimen. Direction of growth, [001]. Lowering speed, $6.3 \mathrm{~mm} / \mathrm{min} 99.21 \%$ pure $\mathrm{Ni}$.

(a)

\begin{tabular}{|c|c|c|c|c|c|c|}
\hline $\begin{array}{l}\text { Width of } \\
\text { sub-struct. } \\
(\mathrm{mm})\end{array}$ & 0.18 & $\begin{array}{llll}3 & 0.40 & 0.36 & 0\end{array}$ & .400 .3 & 0.3 & 380.2 & 0.10 \\
\hline$\Delta \phi(\min )$ & & $+24|-55|-22$ & +2 & +164 & -97 & +95 \\
\hline$\Delta \theta(\min )$ & & $+3+8-3$ & -1 & -4 & +10 & -7 \\
\hline & 14 & ded from the & abov & ve row & & \\
\hline $\begin{array}{l}\text { Width of } \\
\text { sub-struct. } \\
(\mathrm{mm})\end{array}$ & 0.1 & $\begin{array}{lll}0 & 0.13 & 0.50\end{array}$ & 0.100 .1 & 10 & .100 & .180 .36 \\
\hline$\Delta \phi(\min )$ & -2 & $-25-32-2$ & +8 & -156 & -24 & +111 \\
\hline$\Delta \theta(\min )$ & +3 & $+3-2+6$ & +1 & -10 & -14 & 0 \\
\hline & & (b) & & & & \\
\hline $\begin{array}{l}\text { Distance al } \\
\text { growth dir } \\
(\mathrm{mm})\end{array}$ & & 0 & 4 & & 7 & 10 \\
\hline$\Delta \phi(\min )$ & & $\begin{array}{l}+164 \\
-\quad 97\end{array}$ & $\begin{array}{r}+172 \\
-\quad 93\end{array}$ & & $\begin{array}{r}174 \\
89\end{array}$ & $\begin{array}{l}+174 \\
-\quad 91\end{array}$ \\
\hline$\Delta \theta(\min )$ & & $\begin{array}{l}-4 \\
+10\end{array}$ & $\begin{array}{l}-9 \\
+10\end{array}$ & + & $\begin{array}{r}5 \\
+10\end{array}$ & $\begin{array}{l}-5 \\
+9\end{array}$ \\
\hline
\end{tabular}

度西境界は試料軸の回りに $(\Delta \phi) 3^{\circ}$ 近い方位差を示すが， 筋の方位差もまた增加し, 数分から小角度西境界に近い位 のものが見出される・なおここで示した方位差を，倜々に
筋あるいは小角度覀境界と対応づけてはいないが，前者に 属すると思われる方位差は数分程度のものを除いて，それ ぞれ 25'，50'，100' のいづれかに近い値をとり，2 倍の比率 で增加する傾向が方ると考学られる。一方 $\Delta \phi$ に較べて試 .料軸に面角な軸の回りの方位差 $(\Delta \theta)$ は小さく, $10^{\prime}$ 以下に 過ぎない: また $\Delta \phi, \Delta \theta$ ともに, 回転方向の符号をも考虑 した場合, 一方向の方位差の和は他の方向のそれにほぼ等 しいが，隣接した亜境界の個々の組についてはこのような 関係は成立しない. Table 2 (b)は亜境界の方位差が成長と ともに数分以内で不規則に変化することを示すが，さらに この变化以内で方位差がー定していることから, Table 2 (a) に示した方位差は与えられた降下速度での定常值であ ることが確かめられる．上述の結果は $99.21 \%$ の試料に ついて示したが, $98.51 \%$ の試料において子同様な結果が 得られた。しかし, 降下速度にともなら筋組織の方位差の 変化は低純度の試料の方がより顕著である。ここで観察さ れた亜境界はまた成長方向に関して大さな異方性を示し, 試料軸が (100) 面内で〔001]方向に数度傾けて成長させた 試料では試料軸方向にあると考えられる温度勾配には関係 なく，[001]方向に一致して現われる(Photo.7).なお, [001]方向の两境界が存在する場合には, 前述の 自状組織 は発生しないことが以上の写真等において注目される.

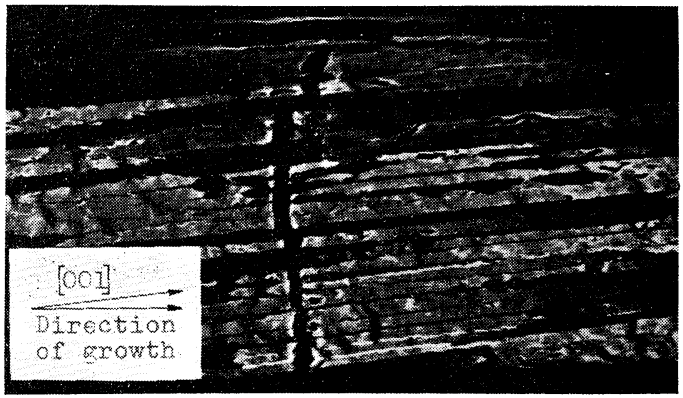

Photo.7 X-ray micrograph on the side surface. [001] axis is inclined at 6 degrees to the direction of growth. Lowering speed, $2.2 \mathrm{~mm} / \mathrm{min} 98.51 \%$ pure $\mathrm{Ni}$.

既報の如く(1)，98.51\%の試料では降下速度が $10 \mathrm{~mm}$ $/ \mathrm{min}$ に達すると試料側面の線状組織は消光, 平均径 0.3 $\mathrm{mm}$ の粒状組織が現われるが，X線回折顕微像においても これと対応した粒状組織が見られ，粒相互の間に数度以下

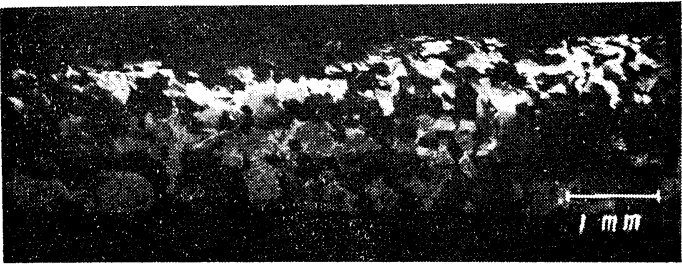

Photo.8 X-ray micrograph on the side surface. Direction of growth, [001]. Lowering speed, $9.78 \mathrm{~mm} / \mathrm{m} 1 \mathrm{n} 98.51 \%$ pure $\mathrm{Ni}$.

の方位差が観察される (Photo.8)，一方 $99.21 \%$ の試料 では $10 \mathrm{~mm} / \mathrm{min}$ 以上の降下速度に扣いてもな扣線状の車 
境界が観察される。しかし，その間隔は $10 \mathrm{~mm} / \mathrm{min}$ 以下 の場合とは逆に降下速度の增加とともに直線的に增加し，

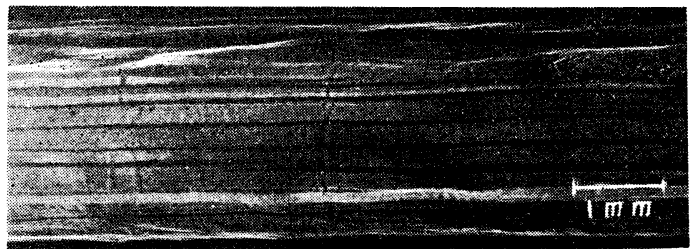

Photo.9 X-ray micrograph on the side surface. Direction of growth, [001]. Lowering speed, $11 \mathrm{~mm} / \mathrm{min} 99.21 \%$ pure $\mathrm{Ni}$.

同時に方位差も平均に大さくなる。ょた同じ回転方向の方 位差をもつ小角度西境界が多くなり，少数の逆方向のもの に方位差の急な增加が見られる (Photo.9). さらに降下速 度が増加しても粒状組織は現われず，[010]拉よび [010] 方向に階段状に広がりながら成長する樹枝状組織が発達し てくる (Photo.10) . 樹枝状晶間の方位差は大さく, 数度

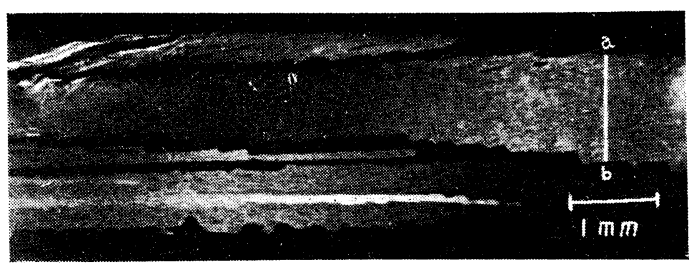

Photo.10 X-ray micrograph on the side surface. Direction of growth, [001]. Lowering speed, $25.4 \mathrm{~mm} / \mathrm{min} 99.21 \%$ pure $\mathrm{Ni}$.
れた下部組織の成因について考察を行つてみる。

遅い降下速度で現われる島j状の下部組織はその形状から 凝固後の歪によつて生じたと考えられ, 従つて前記 (1) ま たは (2) の原因があげられる. 現在の実験条件では, 試料 軸汇平行な一軸性の温度勾配が得られるから, 熱歪は発生 し難い、また坩堝の壁による影響は soft-mold 法の使用 汇よつて除き得るから (1) の原因は重要でない。一方試料 の降下速度が遅い場合には, 帯状組織 (banding) として知 られた不純物の偏析層が成長方向に垂直にでさることが予 期される．このような領域は凝固後に前記 (2) に相当した 歪を発生する．著者の用いた試料では低純度のため，この 効果が大きく現われたものと思われる。

$1 \mathrm{~mm} / \mathrm{min}$ 以上の降下速度になると試料軸に平行な小 角度里境界が観察されるが，この小角度亚境界は Photo.2 で述べたような特別な性質をもち, その発生機構について は前記の因子のみでは説明できず, 次の如く考えられる.

Bolling と Tiller(10) は亚境界近傍の固- 液相界面の形を 熱力学的平衡式 (1) の解より求めた.

$$
\begin{aligned}
& T(\infty, 0)-T(x, y)=-\left(\gamma_{S L} / \Delta S\right) \cdot y^{\prime \prime}\left[1+y^{\prime 2}\right]^{-3 / 2}
\end{aligned}
$$

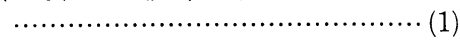

ここで $\Delta S$ は単位体積当りの融解のエントロ'ピー, $\gamma_{S L}$ は単位面積当りの固 - 液相間の界面エネルギーである. い ま $\gamma_{S L}$ が等方的で温度勾配 拈よび小角度亜境界が $y$ 軸に 沿つている場合には，固-液相界面は Fig.2(a) のような 形の凹みを作る. 回みの固相面は適当な曲率をもつて融点

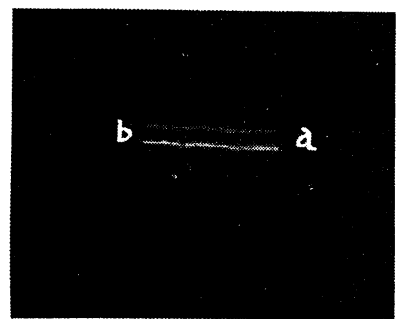

Photo.11 X-ray photograph taken by the use of transmission type monochromater at the line a$\mathrm{b}$ in photo. 10 .

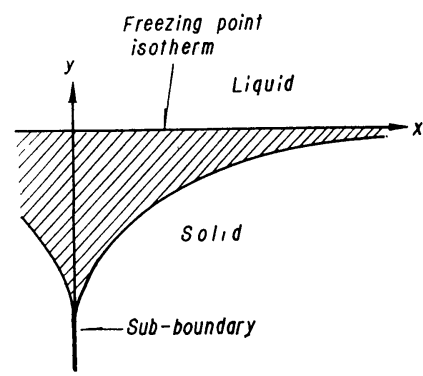

(a)

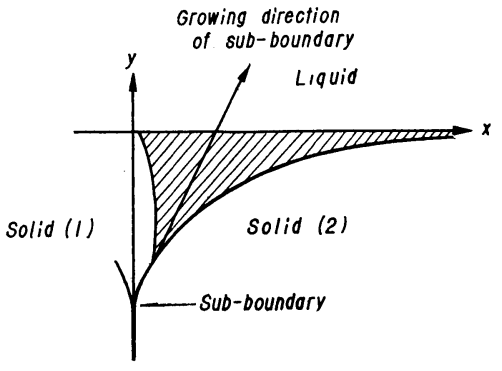

(b)

Fig.2 Schmatic representation of development of sub-structures at the solid-liquid interface.

におよぶこともあるが, 樹枝状晶内の結晶は完全で, 透過 型単色器を用いて調べた結果, 少くとも $1^{\prime}$ 以上の方位差 は認められなかつた(Photo.11)。

\section{IV. 考察}

小角度の亜境界をもつ下部組織の発生原因としては，凝 固過程における転位の発生, ならびにその配列機構と関連 して，(1) 熱歪および坦堝と試料間の熱膨張係数が異なる ために生ずる歪. (2) 不純物の不均一な分布にともなつて 発生する歪. (3) 過飽和の格子空孔の凝縮によつてできた 転位の特殊な配列. (4) 種の結晶に含まれている亜境界の 成長。（5）樹枝状成長の結果としてて樹枝状晶間にできる曲 境界，などが知られている，以下に扣いて，ここで観察さ
$T(\infty, 0)$ より低い温度 $T(x, y)$ で融液と平衡しているか ら, 図中斜線の部分に過冷却領域ができる. 結晶がこのよ うな凝固面をもつて成長している場合には，成長途中であ る種の原因, 例えば降下速度の一時的な増加が起ると, 小 角度亜境界の極く近傍は過冷却度が大さいから，この部分 より樹枝状成長が始まる，樹枝状成長の速度は大きく，ま た成長中に結晶方位を变化するから，もとの固-液相界面 の底の一部汇沿つて, $y$ 軸とある傾斜をもつた小角度亜境 界がでさる.この傾斜した小角度覀境界に平衡する固-液 相界面はFig.2(b) のよ5な形をとり, 結晶成長の進行と ともに小角度亜境界は一時的に矢印の方向に成長する。し

(10) G.F. Bolling and W.A. Tiller: J. App. Phys., 31 (1960), 1345 
かし，小伤度要境界の両側の結晶の固-夜相界面は，(1) 式 の解から融点の位置に括いて互に翼なつた界面エネルギー をむたなければならないが，河者の綰晶方位差は小さく， それ故心同じ程度の界面エネルギーをとるうとする。すな わちこの固一液相界面の形住準安定な状態炕方り，結晶成 長の間に Fig.2(a) の形に戻万らとする．従つて最初試料 軸汇傾いて成長した小角度里境界は资固が進む沉つれ再び 陚料軸虾平行になる。

小角度再境界のできる降下速度で, 低融点会属の場合上 同椂にニッケルでも筋組織が存在することが判る。一般に 筇組織はこの実験仁和いても見られるよらに，結晶成镸中 に成長方向の回りの方位差を增加するが，このような性筫 の解彩之関連してその発生機榡が前記 (3) の原因に上つて 与兄られている。さらに現在の钼察は線状組織の原因の一 部を説明する。すなわら，筋は常に線状組織の境界に一致 して現われておりこのことから線状組織は現在のX線顕

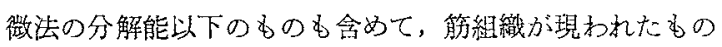
と考光られる.実際に, 放記 (3) の機構に従つて格子空孔
の拡散距離から求めた笳間の間隔は, 線状組織のけ子等し いことを示し得る。しかし，線状組織はまた被組織として の举動をる示し，その成因はさらに複雑で一層の考察は不 純物境界の锶察結果とともに別の機会に瓣告する。

$99.21 \%$ の試料では $10 \mathrm{~mm} / \mathrm{min}$ 程度の降下速度から小 角度亚境界の巾は急に厇くなるが，すでにこの降下速度か ら早い、降下速度で観察されるような樹枝状成長が始要るた めと考党られる. $98.51 \%$ の試料では明膫な樹枝状晶は見 られないが, $10 \mathrm{~mm} / \mathrm{min} の$ 降下速度で急に粒状組織を生 している。この粒の径は同程度の降下速度で成長させた $99.21 \%$ に見られる小角度亚境界の巾にほぼ等しく，拓そ らく低純度のために起る副枝状成長の特殊な場合と思われ る゙.さらに樹枝状晶閶の方位差に関する規則性, あるいは 樹枝状晶内の完全性などは與味ある結果であるが今後の闍 琶で昰石。

終りに臨み，本研究について終始御指導をいただいた京 都大学高木秀夫教授に深謝します。 